\title{
ARTYKUtY
}

Klio. Czasopismo poświęcone dziejom Polski i powszechnym

PL ISSN 1643-8191, t. 47 (4)/2018, s. 41-57

(c) (1) $\Theta$

http://dx.doi.org/10.12775/KLIO.2018.049

HANNA APPEL

\section{Z dziejów badań nad frekwencją uyborczą w późnorepublikańskim Rzymie}

\section{Insights into the History of Studies of Voter Turnout in the Late Roman Republic}

Streszczenie: Aczkolwiek na temat wyborów w republikańskim Rzymie wiemy stosunkowo dużo, to jednak o frekwencji wyborczej w gruncie rzeczy nie wiemy nic, ponieważ antyczne źródła milczą na ten temat. Pomimo to, a może właśnie dlatego, współcześni historycy starają się dokonać stosownych obliczeń, opierając się na pośrednich danych. W związku z tym, zastanawiając się nad odpowiedzią na pytanie, ilu Rzymian głosowało każdego roku na poszczególne urzędy, biorą pod uwagę m.in. takie faktory jak miejsce wyborów oraz czas potrzebny na ich przeprowadzenie. $Z$ takich szacunkowych wyliczeń jedno wynika niezbicie, a mianowicie fakt, że udział obywateli wyborach był niewielki, zwłaszcza w porównaniu z frekwencją wyborczą we współczesnych państwach demokratycznych. Autorka artykułu analizuje przyczyny takiego stanu rzeczy i próbuje odpowiedzieć na pytanie, dlaczego w ogóle jakaś część obywateli, pomimo niemałych niedogodności zwią-

Uniwersytet Mikołaja Kopernika, Wydział Nauk Historycznych, ul. Bojarskiego 1, 87-100 Toruń, hanna.appel@umk.pl, ORCID: 0000-0002-0342-3469. 
zanych z dokonaniem aktu wyborczego, udawała się każdego roku na zgromadzenia wyborcze, by poprzez swój głos umożliwić członkom arystokracji pokonywanie kolejnych etapów urzędniczej „ścieżki zaszczytów” (cursus honorum).

\begin{abstract}
While relatively much is known about elections in the republican Rome, we know nothing in fact about the voter turnout as the ancient sources are silent on this topic. Despite, or perhaps because of this, contemporary historians seek to make such calculations on the basis of indirect data. Hence, in order to estimate how many Romans cast their votes for respective offices each year, they consider such factors as the venue and time necessary for holding such elections. One aspect is shown clearly by such estimates: that the citizen participation in the elections was insignificant, especially in comparison with the voter turnout in modern democracies. The author analyses the reasons for this state of affairs and seeks to answer the question why, in spite of considerable inconveniences involved in the act of voting, some portion of the citizenry did, after all, attend the electoral conventions each year, using their votes to help members of the aristocracy along the stages of their 'course of honours' (cursus honorum).
\end{abstract}

Słowa kluczowe: wybory, frekwencja wyborcza, zgromadzenia wyborcze, późna republika rzymska.

Keywords: elections, voter turnout, electoral conventions, late Roman Republic.

Tie ulega najmniejszej wątpliwości, że „wybory stanowiły w życiu sta1 rożytnej polis, a Rzym aż do końca republiki pozostał pod względem ustroju państwem-miastem, moment centralny działalności politycznej, w nich przejawiała się władza ludu nadawania najwyższych godności państwowych swym wybrańcom"1. I kiedy czytamy antyczne źródła, możemy odnieść wrażenie, że w okresie późnej republiki rzymskiej wybory cieszyły się ogromnym zainteresowaniem. Z lektury tej wynika, że klasa posiadająca angażowała dużo czasu, energii i pieniędzy w kampanię wyborczą ${ }^{2}$. Wśród badaczy panuje opinia, że zgromadzenia wyborcze były ważne dlatego, że to właśnie na nich zapadały najistotniejsze decyzje personalne, a dzięki nim

${ }^{1} \mathrm{~J}$. Linderski, Rzymskie zgromadzenia wyborcze od Sulli do Cezara, Wrocław-Warszawa-Kraków 1966, s. 5.

${ }^{2}$ H. Mouritsen, Plebs and Politics in the Late Roman republic, Cambridge 2001, s. 90 , przyp. 1 . 
każdy arystokrata wybrany na jakiś urząd miał już do końca życia zapewnione miejsce w senacie i od tej pory należał do społecznej elity. Wybór na określony urząd dawał więc szansę na zdobycie władzy, a tym samym wpływów oraz bogactwa, nawet na możliwość prowadzenia wojennych kampanii i czasem na odbywanie triumfów ${ }^{3}$. Jest zatem zupełnie zrozumiałe, że dla arystokracji, z której wywodzili się kandydaci, wybory były niezwykle ważne. Nie do końca natomiast jest rzeczą pewną, czy tak samo ważne były one dla ich wyborców, i czy wybór nowych urzędników wzbudzał zainteresowanie także tych obywateli, którzy nie należeli do elity urzędniczej. Wśród pytań nurtujących obecnie historyków pojawiają się też bardziej konkretne: ilu Rzymian głosowało każdego roku na zgromadzeniach wyborczych? ${ }^{4}$, i kto w nich uczestniczył?

$\mathrm{Na}$ to ostatnie pytanie Martin Jehne z rozbrajającą szczerością odpowiada: nobody knows 5 . I rzeczywiście: nikt tego dokładnie nie wie, ponieważ w dostępnych źródłach nie znajdujemy nawet najmniejszej wskazówki co do tego, jakie liczby wchodziły tu w grę. I chociaż wiadomo, że nie zdołamy w tej materii ustalić z całą pewnością niektórych faktów, to jednak współcześni badacze podejmują próby „policzenia” tych obywateli, którzy brali udział w wyborach. Szczególną okolicznością sprzyjającą szerszemu

${ }^{3}$ Zob. E. Flaig, Entscheidung und Konsens. Zu den Feldern der politischen Kommunikation zwischen Aristokratie und Plebs, [w:] M. Jehne, Demokratie in Rom?: die Rolle des Volkes in der Politik der römischen Republik, Stuttgart 1995, s. 77 i n. Por. E. Flaig, Zrytualizowana polityka. Znaki, gesty i wtadza w starożytnym Rzymie, przekł. L. Mrozewicz, A. Pawlicka, Poznań 2013, s. 167: „Dla arystokracji wybory były na ogół najważniejszym tematem politycznym. Dla plebsu już raczej nie, chociaż ich wynik miał często bezpośredni wpływ zarówno na poszczególnych plebejuszy, jak i na całe grupy wyborców".

${ }^{4}$ Zob. np. R. McMullen, How many Romans voted?, „Atheneum” 1980, 58, s. $454-457$.

${ }^{5}$ M. Jehne, Who Attended Roman Assemblies? Some Remarks on Political Participation in the Roman Republic, [w:] F. Marco Simón, F. Pina Polo and J. Remesal Rodríguez, Repúblicas y ciudadanos: modelos de participación civica en el mundo antiguo, Barcelona 2006, s. 221-234.

${ }^{6}$ C. Nicolet, Obywatel, polityk [w:] A. Giardino, Cztowiek Rzymu, przekł. P. Bravo, Warszawa 1997, s. 51, ma zapewne rację, twierdząc, że „nie jest (...) pewne, czy prowadzono taką buchalterię przy systemie głosowania przez zbiorcze jednostki. Pewna jest natomiast zmienność uczestnictwa, zależna od okoliczności i, na dłuższą metę, od zmian instytucjonalno-politycznych". 
zainteresowaniu się tym problemem było pojawienie się artykułów Fergusa Millara $^{7}$, w których próbował on dowieść, że „Rzym był bliżej ateńskiej demokracji niż sądzimy" ". Sformułował on taki wniosek, krytycznie odnosząc się do stanowiska w badaniach historyków, które pomijało rolę ludu - jako czynnika nieistotnego - w życiu politycznym republiki. Zdaniem Millara zaś to właśnie lud w republice rzymskiej był suwerenem, ponieważ to on miał decydujące zdanie przy wyborach na urzędników, a także przy podejmowaniu decyzji dotyczących wojny i pokoju oraz w kwestiach legislacyjnych? ${ }^{9}$ Trudno nie zgodzić się ze zdaniem Millara w tej kwestii, że to populus Romanus decydował o tym, komu zostaną przyznane honores, jednocześnie jednak łatwo zauważyć, że ów decydent nie mógł ani na ten temat debatować, ani też nie miał prawa inicjować wyłonienia nazwisk kandydatów ${ }^{10}$. Poglądy Millara sprawiły, że niemal każdy badacz, który zajmował się problemami republiki rzymskiej, „poczuł się niejako wywołany do tablicy” i uznał za stosowne wypowiedzieć się w tej kwestii ${ }^{11}$. A problem fre-

${ }^{7}$ F. Millar, The Political Character of the Classical Roman Republic, "Journal of Roman Studies" 1984, 74, s. 1-19; Politics, Persuasion, and the People before the Social War (150-90BC), „Journal of Roman Studies” 1986, 76, s. 1-11; Political Power in MidRepublican Rome: Curia or Comitium, „Journal of Roman Studies” 1989, 79, s. 138-150.

${ }^{8}$ F. Millar, The Political..., s. 2. O poglądach Millara zob. A. Ziółkowski, Historia Rzymu, Poznań 2008, s. 290-291. Por. K.J. Hölkeskam, Rekonstruktionen einer Republik. Die politische Kultur des antiken Rom und die Forschung der letzten Jahrzehnte, München 2004; M. Jehne, Einführung: Zur Debatte um die Rolle des Volkes in der romischen Republik, [w:] M. Jehne, Demokratie in Rom?, s. 1-10.

${ }^{9}$ M. Jehne, Who attended..., s. 223. Autor stwierdza, że nie jest przekonany do poglądów Fergusa Millara odnośnie do rzymskiej demokracji, ale przyznaje, że sprowokował on ożywioną dyskusję na ten temat, a sam dał wiele prowokujących odpowiedzi, które $\mathrm{z}$ kolei stały się bodźcem do badania funkcjonowania całego systemu politycznego.

${ }^{10}$ H. Beck, Karriere und Hierarchie. Eine Studie zur römischen Aristokratie in der mittleren Republik, Köln 2005, s. 22. A. Ziółkowski, op. cit., s. 270: „Lud rzymski był nie tylko pasywny politycznie, ale również niemal doskonale niemy. Podczas zgromadzenia nie miał możliwości wyrażania swych opinii w materii będącej przedmiotem zgromadzenia inaczej niż krzykiem, gwizdami, ewentualnie kamieniami”. Por. także M. Finley, Polityka w świecie starożytnym, tłum. D. Kozińska, Kraków 2000, s. 112.

${ }^{11}$ Zob. np. F. Pina Polo, Contra arma verbis. Der Redner vor dem Volk in der späten romischen Republik, tłum. z hiszpańskiego E. Liess, „Heidelberger Althistorische Beitrage und Epigraphische Studien 22", Stuttgart 1996, s. 8. Badacz przytacza poglądy innych 
kwencji wyborczej jest, jak się zdaje, jednym z najistotniejszych zagadnień odnoszących się do polemiki toczącej się wokół „demokracji” w Rzymie. Zanim omówimy tę kwestię, warto przypomnieć podstawowe fakty dotyczące samych wyborów.

Każdego roku lud zgromadzony na comitia tributa wybierał niższych urzędników (magistri minores), natomiast na comitia centuriata urzędników wyższych (magistri maiores). W sumie (w okresie posullańskim) wybierano około 40 urzędników ${ }^{12}$, a ponadto 24 trybunów wojskowych. Na komicjach tribusowych obywatele gromadzili się według 35 tribus, natomiast na komicjach centurialnych głosowali według przynależności do 193 centurii $^{13}$. Przynależność do określonych centurii zależała od wieku (iuniores byli w wieku 17-45 lat, a seniores $45-60$ ? $)^{14}$ i cenzusu majątkowego. Sam system wyborczy był niezwykle skomplikowany, a procedury stosowane na komicjach były różne ${ }^{15}$. Comitia tributa odbywały się zazwyczaj na forum przy świątyni Kastora i Polluksa oraz na Kapitolu, natomiast comitia centuriata zawsze na Campus Martius - poza pomoerium. Dzięki temu, że znamy lokalizację zgromadzeń, możemy dokonać próby wyliczenia, ilu wyborców mogły one pomieścić. Takie symulacje przeprowadzili m.in. Lily Ross Tay-

historyków (m.in. Nicoleta, Lintotta, Burkhardta) sprowokowanych tezami zawartymi w artykułach Millara.

${ }_{12}$ Wiadomo, że co roku wybierano 44 urzędników, a w latach, kiedy wybierano cenzorów, było ich 46 .

${ }^{13}$ Podział na centurie wprowadził Serwiusz Tuliusz w V wieku p.n.e. Zgromadzenie centurialne pochodziło z pierwotnego zgromadzenia wojskowego, ale w ostatnim wieku republiki nie miało ono nic wspólnego z organizacją wojskową, zob. J. Linderski, Rzymskie..., s. 8; por. T.P. Wiseman, The census in the first century B.C., „Journal of Roman Studies" 1969, 59, s. 59-75. O zgromadzeniu Serwiusza zob. Liv. 1, 43; Dion. Hal. 4,16; Cic. Rep. 2, 39-41.

${ }^{14}$ Ów podział na iuniores i seniores potwierdza militarny aspekt zgromadzenia.

15 W III wieku comitia centuriata zostały zreformowane. Szczegóły reformy nie są do końca znane (chodziło głównie o połączenie tribus z centuriami), dyskusja badaczy na ten temat toczy się od bardzo dawna. J. Linderski, op. cit., s. 8-22, przywołuje wcześniejsze poglądy historyków, wśród najnowszych na uwagę zasługują artykuły L. Grieve, Livy 40.51.9 and the Centuriate Assembly, „Classical Quarterly” 1985, 35, s. 417-429 oraz The Reform of the Comitia Centuriata, „Historia” 1985, 34, s. 278-309, por. także M. Jehne, Integrationsrituale in der römischen Republik, [w:] G. Urso, Integrazione, mescolanza, rifuto, Roma 2001, s. 89-112. 
lor $^{16}$, Ramsey MacMullen ${ }^{17}$, a ostatnio Henrik Mouritsen ${ }^{18}$, który wziął pod uwagę więcej faktorów - np. minimalny czas konieczny do przeprowadzenia procedury wyborczej - aniżeli tylko potencjalną liczbę wyborców, którzy mogli się zmieścić w miejscu przeprowadzanych wyborów.

Wspomniana L. Taylor w swoich wyliczeniach wzięła pod uwagę liczbę obywateli, którzy mogli głosować w tzw. Saepta Iulia ${ }^{19}$ w czasie wyborów na zgromadzeniu trybusowym. Zdaniem badaczki w 35 wąskich alejkach (każda tribus głosowała osobno) mogło się zmieścić maksymalnie 70 tys. głosujących. MacMullen uważa, że jest to liczba zawyżona, i twierdzi, że jednego dnia w takich warunkach mogło głosować najwyżej 55 tysięcy. Niezależnie od tego, która z tych liczb jest bliższa prawdy, to z faktu, że w 28 roku p.n.e. 1700000 rzymskich obywateli (dorosłych mężczyzn) ${ }^{20}$ miało prawo wyborcze, niezbicie wynikać będzie, że był to niewielki odsetek, sięgający $2 \%$ lub mniej ${ }^{21}$.

${ }^{16}$ L.R. Taylor, Roman Voting Assemblies, Ann Arbor 1966, s. 52-54.

17 R. McMullen, How many Romans voted?, „Atheneum” 1980, 58, s. 454-457.

${ }_{18}$ H. Mouritsen, Plebs and Politics..., s. 18-37; idem, Politics in the Roman Republic, Cambridge 2017, s. 55-58. Zob. także D.A. Phillips, Voter Turnout in Consular Elections, „Ancient History Bulletin” 2004, s. 49 i n.

${ }_{19}$ O tej budowli Cyceron pisze do Attyka w liście 1 lipca 54 roku (Att. 4, 16, 8: „Dokonamy dzieła, które nam przysporzy wiele chwały: wzniesiemy na Polu Marsowym marmurowe ogrodzenia dla zebrań wyborczych, pokryjemy je dachem i otoczymy wysokim portykiem długim na tysiąc kroków” (przekład G. Pianko). Tysiąc kroków, jak obliczono, to długość ok. 1,7 km. Zdaniem R. MacMullena, op. cit., s. 454, nikt dzisiaj nie wierzy, że faktycznie powstała tak okazała budowla. Przyjmuje więc, że Saepta Iulia miała 250 m długości i 95 m szerokości (nie licząc portyków). Z kolei H. Mouritsen, Politics..., s. 57, uważa, że: „Saepta Iulia to prostokąt $310 \mathrm{~m}$ na $120 \mathrm{~m}$ ”. Niezależnie od tych kontrowersji C. Nicolet, Obywatel..., s. 54, trafnie stwierdza, że ,jak na ironię ta wspaniała budowla została postawiona w chwili, gdy Cesarstwo wypierało republikę, a komicja właśnie stawały się przeżytkiem".

${ }^{20}$ C. Nicolet, Obywatel..., s. 290; R. MacMullen, op. cit., s. 455. Autor uważa, że w 200 roku p.n.e. uprawnionych do głosowania było 250 tys. mężczyzn, w 150 roku 375 tys., w 100 roku 425 tys., a w 70 roku milion.

${ }^{21}$ Zob. R. MacMullen, op. cit., s. 455 i n. Autor dokładnie analizuje także warunki, w jakich przeprowadzano wybory na forum przed świątynią Kastora. Ustalenie przestrzeni nie jest łatwe, ponieważ na tym terenie stały także inne obiekty, np. tribunal praetorium. Niemniej według R. MacMullena było tam miejsce dla ok. 20 tys. osób. 
Jak trudne, niepewne i tylko orientacyjne są to wyliczenia, pokazuje następujący przykład. Otóż Nicolet próbuje dokonać obliczeń na podstawie czasu potrzebnego do przeprowadzenia wyborów w roku $45^{22}$, o których wiemy, że trwały wówczas pięć godzin. Badacz założył, że głosowało wtedy 97 centurii (liczba wymagana do uzyskania większości), a wyborcy w swoich 35 kolumnach (po jednej dla każdej tribus) posuwali się w tempie dwóch osób na minutę; obliczył więc, że w ciągu pięciu godzin mogło zagłosować około 16800 obywateli. Ogólną wartość tych jednostkowych ustaleń zakwestionował $\mathrm{H}$. Mouritsen, który zwrócił uwagę na fakt, że Nicolet bazuje na sytuacji absolutnie wyjątkowej. Dzięki Cyceronowi wiemy, że 31 grudnia 45 roku wybory na kwestorów w sposób nieoczekiwany zostały przekształcone w wybór na urząd konsula. Jak zaznacza Mouritsen, w swoich wyliczeniach Nicolet nie wziął pod uwagę tego, że akurat w tym szczególnym wypadku należało dokonać reorganizacji zgromadzenia, a także uwzględnić głosowanie centuria praerogativa ${ }^{23}$, co również musiało zająć trochę czasu. Zdaniem badacza nie bez znaczenia były także inne czynniki, np. liczebność poszczególnych tribus (a różnice między nimi były duże). $\mathrm{Z}$ jego kalkulacji, po uwzględnieniu wymienionych okoliczności, wynika, że nie 16 800, a tylko 6 tys. obywateli mogło wziąć udział w tych wyborach.

Omawiany przykład był na tle innych z pewnością wyjątkowy i trudno byłoby tylko na jego podstawie wyrobić sobie miarodajną opinię o udziale ludu w wyborach. Ostatecznie w podsumowaniu swoich rozważań na temat frekwencji wyborczej H. Mouritsen stwierdził, że do 145 roku p.n.e. tylko nieco więcej niż $1 \%$ obywateli brało udział w uchwalaniu ustaw i w wyborach na niższych urzędników. Natomiast analizując dane dotyczące wyborów na wyższe urzędy, badacz wziął pod uwagę domniemaną kuba-

22 C. Nicolet, Obywatel..., s. 291. Cic. Fam. 7,30: Hora secunda comitiis quaestoriis institutis... ile autem... centuriata habuit, consulem hora septima renuntiavit. Chodziło tu o wybór Caniniusa Rebillusa, który sprawował swój urząd konsula zaledwie kilka godzin, a Cyceron dowcipnie podsumował ów konsulat, stwierdzając, że w czasie jego trwania nikt nie jadł śniadania: Caninio consule scito neminem prandisse.

${ }^{23}$ Centuria praerogativa wyłoniona drogą losowania spośród centurii pierwszej klasy głosowała jako pierwsza. Na ten temat zob. szczegółowo: Chr. Meier, s.v. praerogativa centuria, RE Suppl. 8, 1956, 567-598; por. M. Jehne, Wirkungsweise und Bedeutung der centuria praerogativa, „Chiron” 2000, 30, s. 661-678. 
turę Saepta, która mogła pomieścić 3\% z około 910 tys. mężczyzn uprawnionych do głosowania zarejestrowanych w 70/69 roku p.n.e. W samym Rzymie było 200 tys. uprawnionych do głosowania dorosłych mężczyzn, ale prawdopodobnie tylko ok. $12 \%$ brało udział w wyborach ${ }^{24}$.

Jak widać, od tego, jakie okoliczności weźmiemy pod uwagę, badając problem uczestnictwa w zgromadzeniach wyborczych, zależeć będą liczby dotyczące przypuszczalnej frekwencji wyborczej w późnorepublikańskim Rzymie. Wyliczenia te uwzględniają jedynie niektóre dostępne dane na temat wyborów, wszystkie są zatem niedoskonałe. Podkreślić wszakże należy, że niezależnie od okoliczności owa frekwencja, zwłaszcza w porównaniu z frekwencją w wyborach przeprowadzanych współcześnie, była zawsze niska ${ }^{25}$. Warto stwierdzenie to opatrzyć uwagą, że badacze są zgodni co do tego, że frekwencja na wyborach urzędników była wówczas mimo wszystko wyższa ${ }^{26}$ niż na zgromadzeniach legislacyjnych.

Nie mamy żadnych informacji na temat wymaganego quorum, które warunkowałoby prawomocność wyborów. Zapewne takiego quorum nie było. Co ciekawe zaś, również ustawy mogły być uchwalone przy niewielkiej frekwencji, nawet te najważniejsze. Jest to tym bardziej zdumiewające, że, o ile nam wiadomo, frekwencja w senacie była przedmiotem troski wielu polityków. Sam Cyceron wspomina o niej aż 23 razy $^{27}$.

${ }^{24}$ H. Mouritsen, Plebs and Politics..., s. 32. Por. M. Jehne, Who attended..., s. 224.

${ }_{25}$ Trzeba jednak wspomnieć także o (rzadkich) wzmiankach źródłowych na temat dużej liczby zgromadzonych obywateli: Liwiusz 45, 36,6, pisze o tym, że żołnierze przybyli tak tłumnie, by odrzucić wniosek w sprawie triumfu Emiliusza Paulusa, iż nie starczyło miejsca dla innych. Plutarch, $G G$ 3,2 wspomina o tym, że „lud całymi tłumami płynął na te wybory tak licznie, że dla bardzo wielu zabrakło miejsca w domach. I Pole Marsowe także nie mogło ich pomieścić, tak że głosy wyborców rozlegały się nawet z poddaszy i samych dachów" (przekład M. Brożka). M. Jehne, Who attended..., s. 224, przyp. 26, zwraca uwagę na fakt, iż podane przez Plutarcha szczegóły są nierealne, były to bowiem czasy, kiedy każdy głos zapisywany był na tabliczkach.

${ }^{26}$ Nasze źródła najczęściej mówią o wyborach na konsulów.

27 Zob. H. Mouritsen, Plebs and Politics..., s. 33, przyp. 55. W senacie czasami obowiązywało quorum. 
Nie słyszymy o tym, by kwestionowano wynik wyborów z powodu frekwencji ${ }^{28}$. Warto zatem zastanowić się nad tym, dlaczego tak niewielka część obywateli mających prawo wyborcze z tego prawa korzystała ${ }^{29}$.

W tym kontekście Bernard Linke ${ }^{30}$ zadaje bardzo konkretne pytanie: „kto jest ludem?”, albo raczej: gdzie jest ów wyborczy populus, skoro tak mała liczba jego przedstawicieli pojawia się na zgromadzeniach? Odpowiedź na to pytanie, jego zdaniem, jest oczywista. Otóż od połowy IV wieku Rzymianie osiedlali swoich obywateli na zdobytych terytoriach. Obywatele posiadający prawa wyborcze mieszkali zatem nie tylko w Rzymie, ale w całej Italii. Tymczasem struktury organizacyjne wcale się nie zmieniały, nie były dostosowywane do nowych warunków. Rzym nadal funkcjonował jak miasto-państwo. Każdy, kto chciał być aktywny politycznie, musiał zatem po prostu udać się do Rzymu. Takie wyprawy bywały bardzo kosztowne. Zdaniem B. Linkego narażenie na koszty, które trzeba było ponieść, by skorzystać z praw wyborczych, można w pewnym sensie porównać do działania systemu cenzusowego. Im dalej bowiem od Rzymu mieszkali obywatele, tym większe musieli w związku z tym ponieść wydatki ${ }^{31}$. Fakt, iż obywatele mogli głosować tylko w Rzymie, pokazuje, na jaką skalę uczestnictwo w wyborach było utrudnione; kiedy zaś sprzymierzeńcy wywalczyli sobie obywatelstwo rzymskie w 70 roku p.n.e., sytuacja stała się wręcz absurdalna, ponieważ od tej chwili większość obywateli mieszkała poza Rzymem,

${ }_{28}$ M. Jehne, Who attended..., s. 225, przyp. 27, zwrócił uwagę na bardzo ciekawe obliczenia Pfeilschiftera, że liczba potencjalnych wyborców zmniejszała się dramatycznie w okresie republiki. Na początku głosowało 100\% uprawnionych do głosowania, po wcieleniu większości Latynów w 338 r. - odsetek zmalał do 40\%, przed II wojną punicką wynosił już tylko 20\%, a w ostatnich dekadach republiki wynosiła ok. 5\%.

${ }^{29}$ Z całą pewnością w latach politycznych napięć i konfliktów była ona różna, ale nie chodzi tutaj o szczegółowe przedstawienie wyborów w poszczególnych latach późnej republiki rzymskiej.

${ }^{30}$ B. Linke, Bürger ohne Staat? Die Integration der Landbevölkerung in der römischen Republik, [w:] M. Jehne, R. Pfeilschifter, Herrschaft ohne Integration? Rom und Italien in Republikanischer Zeit, Frankfurt 2006, s. 65-95. Zob. także A. Ziółkowski, op. cit., s. 269.

${ }^{31}$ B. Linke, op. cit. s. 72 i n. Badacz zwraca uwagę na bardzo interesujący fakt,: „(...) zatem wytworzyła się taka sytuacja, że ci, którzy korzystali z praw na zgromadzeniach, już nie brali udziału w walkach. W rzeczywistości były dwa światy: jedni byli obecni w polityce, inni aktywni militarnie", ibidem, s. 73 . 
a w nim musiała przecież głosować. Biorąc pod uwagę fakt, że wybory na poszczególne urzędy odbywały się w różnych terminach, należy stwierdzić, że ci obywatele, którzy chcieliby brać w nich udział, musieliby udawać się do Rzymu kilka razy w roku ${ }^{32}$.

Wśród innych powodów, które mogły zniechęcać ewentualnego wyborcę do pójścia na wybory, na szczególną uwagę zasługuje system głosowania: ten na komicjach trybusowych był nazywany egalitarnym, natomiast ten na komicjach centurialnych elitarnym ${ }^{33}$. Niezależnie od tego podczas wszystkich wyborów obowiązywał system głosowania grupowego ${ }^{34}$, co oznaczało, że najpierw głosowano w obrębie 35 tribus (lub 193 centurii), a każda z nich jako taka miała jeden głos niezależnie od liczby głosujących $\mathrm{w}$ danej tribus $^{35}$ (lub centurii). Na komicja tribusowe gromadzono się zatem zgodnie z podziałem na 35 okręgów (tribus ${ }^{36}$ ). Procedura w czasie takiego zgromadzenia nie odzwierciedlała żadnej hierarchii ${ }^{37}$, chociaż

32 Zdaniem H. Mouritsena, Plebs and Politics..., s. 95, utrudnienia takie były celowe. C. Nicolet, Obywatel..., s. 50, stwierdza: „Nawet jeśli nie wszyscy spośród trzystuczterystu tys. obywateli (lub miliona w I wieku p.n.e.) brali udział w głosowaniu, operacje i tak ciągnęły się bez końca, jedna po drugiej przez co najmniej dziesięć dni w roku”. Zob. też G. Laser, Populo et scaenae serviendum est. Die Bedeutung der städtischen Masse in der späten römischen Republik, Trier 1997, s. 52 i n.

33 Zob. np. M. Jehne, Integrationsrituale..., s. 100.

${ }^{34} \mathrm{Na}$ temat głosowania grupowego zob. np. E.S. Staveley, Greek and Roman Voting and Elections, London 1972, s. 133 i n. Na temat procedury wyborczej ze szczególnym uwzględnieniem wprowadzenia głosowania na tabliczkach na mocy lex Gabinia zob. m.in U. Hall, Species libertatis. Voting procedure in the late Roman Republic, [w:] M.M. Austin, J.D. Harries i C.J. Smith, Modus Operandi. Essays in Honour of G. Rickman, Institute of Classical Studies, suppl. 71, London 1998, s. 15-30.

35 Zadaniem urzędników było sprawdzenie, czy każda tribus ma swoich reprezentantów. Jeśli było ich mniej niż pięciu, wówczas wyznaczano wyborców z innej tribus. Zob. Cic. Sest. 109: venio ad comitia, sive magistratuum placet sive legum. leges videmus saepe ferri multas. omitto eas quae feruntur ita vix ut quini, et ii ex aliena tribu, qui suffragium ferant reperiantur. Por. L.R. Taylor, Roman Voting..., s. 76.

${ }^{36}$ Każdy dorosły mężczyzna wolno urodzony należał do jakiejś tribus, a przydział do niej był określany albo miejscem, gdzie były jego posiadłości, albo miejscem jego zamieszkania (pobytu), zob. L.R. Taylor, Voting Districts..., s. 3.

37 E. Flaig, Zrytualizowana..., s. 169. Badacz mówi o egalitaryzmie tych zgromadzeń, ponieważ obok siebie stali tu zarówno rzemieślnicy, jak i kupcy rolnicy oraz notable. Nikt też nie miał takiej pozycji, która by go wyróżniała. Do głosowania szło równocześnie 
i tutaj można było mówić o jakimś poczuciu nierówności, ponieważ tribus miejskie (było ich cztery) były traktowane jako gorsze niż wiejskie (31). Natomiast na komicjach centurialnych, podczas których wybierano konsulów, pretorów i cenzorów, „biorący w nich udział obywatele już na wstępie doznawali poczucia społecznej i politycznej nierówności”"38, ponieważ to właśnie ludzie bogaci dysponowali największą liczbą głosów ${ }^{39}$. Ekwici byli podzieleni na 18 centurii (a zatem mieli 18 głosów), pierwsza klasa liczyła po 40 centurii iuniores i seniores (czyli razem miała 80 głosów) ${ }^{40}$, klasa druga, trzecia i czwarta po 10 iuniores i seniores (czyli łącznie 60), piąta klasa po 15 iuniores i seniores (razem było to 30 głosów) ${ }^{41}$. Przed przystąpieniem do właściwych wyborów losowano spośród centurii pierwszej klasy

35 tribus. O przewadze tribus wiejskich nad miejskimi zob. np. C. Nicolet, Obywatel..., s. 51. L.R. Taylor jest autorką opracowania z 1960 r. na temat tribus jako okręgów wyborczych (The Voting Districts of the Roman republic). W 2013 r. ukazało się wznowienie tej książki ze znakomitym jej dopełnieniem autorstwa J. Linderskiego. Omawia on każdy rozdział książki Taylor, uzupełniając go o wyniki nowszych badań, które nieraz nakazują zmianę spojrzenia na niektóre zagadnienia. Nowe świadectwa pozwoliły m.in na inne rozmieszczenie tribus. Owe uzupełnienia Linderskiego pokazują, jak ważne są dalsze badania nad tymi niezwykle trudnymi zagadnieniami.

${ }^{38}$ E. Flaig, Zrytualizowana..., s. 170.

39 Według Nicoleta, Obywatel..., s. 246, fundamentalna zasada głosowania grupowego, a nie indywidualnego, sprawiła, że głosowanie było bardzo formalną operacją, jako że nie liczył się w nim każdy osobny głos. Por. E.S. Staveley, op. cit., s. 133 i n.

${ }^{40}$ Po reformie comitia centuriata liczba centurii zmniejszyła się z 80 do 70, zob. np. E. S. Staveley, op. cit., s. 126.

${ }^{41} \mathrm{O}$ takim podziale na centurie wprowadzonym przez Serwiusza Tuliusza Cyceron pisze tak (rep. 2,39): „Tę dużą grupę jeźdźców potraktował jako osobną całość, a resztę ludności podzielił na pięć klas, odróżniając starszych i młodszych. Głosy tak im przypisał, że nie pospólstwo, tylko ludzie możni i wpływowi decydowali o wyniku głosowania, ponieważ zdaniem króla należało zadbać, by najliczniejsi nie znaczyli najwięcej (...) reszta ludności o wiele liczniejsza, ale skupiona w dziewięćdziesięciu sześciu centuriach, nie została wykluczona z glosowania, co byłoby dowodem lekceważenia, ale ograniczono jej wpływ, by uniknąć niebezpieczeństwa” (przekł. I. Żółtowskiej). Por Liv. 1,43: „Tak więc od ciężarów uwolnił ubogich, a zwalił je na bogatych, ale za to podnosił ich znaczenie polityczne (...) teraz zaś poczynił król stopniowanie, tak że na pozór nikt nie był wykluczony od głosu, a jednak przewagę mieli najznakomitsi obywatele" (przekł. A. Kościółek). 
jedną, tzw. centuria praerogativa, która głosowała jako pierwsza ${ }^{42}$. Potem głosowali kolejno obywatele z pozostałych 69 centurii pierwszej klasy, następnie ekwici ${ }^{43}$, a jeśli dodamy do tego, jak zauważył Cyceron, centurię cieśli i przynajmniej osiem z pozostałych centurii, to taka większość mogła przesądzić o wyniku głosowania na zgromadzeniu ${ }^{44}$. W tym momencie wybory przerywano i pozostali obywatele nie musieli głosować, jako że ich obecność była już zbędna ${ }^{45}$. Trzeba przyznać, że taka okoliczność musiała również działać demotywująco na potencjalnego wyborcę, jeśli należał on do klasy niższej ${ }^{46}$.

Przy badaniach nad zagadnieniem frekwencji wyborczej w późnorepublikańskim Rzymie należy uwzględnić jeszcze jedną okoliczność, tylko pozornie oczywistą, a mianowicie fakt, że ówczesne wybory były spersonalizowane i nie miały takiego politycznego charakteru jak obecnie. Innymi słowy głosowano wtedy na konkretnego kandydata, a nie na jakiś jego program wyborczy ${ }^{47}$.

42 Przedstawiony tutaj przebieg głosowania odnosi się do okresu po reformie centurialnej. O wpływie centuria praerogativa na dalsze głosowanie zob. Cic. Planc. 49; Liv. 26,22,13; 24,7,12-9,2; 26,22,2-14; Cic. Q. Fr. 2,15,4; div. 1.103, 2.83; Mur. 38. Por. wyżej, przyp. 22. Fakt, iż centuria praerogativa byla wybierana tylko spośród centurii pierwszej klasy, również świadczył o hierarchizacji comitia centuriata. Także na zgromadzeniu tribusowym wybierano jedną tribus, która głosowała jako pierwsza (tzw. principium), ale ta była wybierana spośród wszystkich 35 tribus, czyli każda z nich miała szansę na takie wyróżnienie.

43 Przed reformą centurialną ekwici głosowali jako pierwsi, a po reformie dopiero po pierwszej klasie.

44 Zob. Cic. rep. 2,39.

45 Zob. E. Flaig, Zrytualizowana..., s. 172: „dolne klasy cenzusowe mogły czuć się podwójnie dyskryminowane. Ich głosy bezpośrednie nie miały specjalnego znaczenia, a w dodatku ryzykowały każdorazowo, że prowadzący wybory w ogóle ich nie wezwie do oddania głosów”.

46 A. Yakobson, Elections and Electioneering in Rome. A Study in the Political System of the Late Republic, Stuttgart 1999, s. 60, zwraca uwagę na fakt, że jeśli ekwici i pierwsza klasa byli przeciwko jakiemuś kandydatowi, to nie miał on w wyborach żadnych szans. Zdaniem D.A. Phillipsa, op. cit., s. 56, zapewne zdarzało się czasami, że niższe klasy decydowały jednak o wyniku wyborów.

47 Warto w tym kontekście zacytować radę Kwintusa dla kandydującego Cycerona (Com. Pet. 53: „(..) w okresie wyborczym nie powinieneś występować aktywnie ani w se- 
W Rzymie parlament w dzisiejszym tego słowa znaczeniu nie istniał, a siłę legislacyjną miało concilium plebis ${ }^{48}$. Urzędnicy rzymscy, na których głosowali Rzymianie, nie reprezentowali więc swoich wyborców tak, jak współcześni politycy, nasi kandydaci do parlamentu ${ }^{49}$. To, co wydaje się współcześnie decydujące o zainteresowaniu wyborami, to odniesienia do polityki, natomiast kampania wyborcza w republikańskim Rzymie była raczej apolityczna ${ }^{50}$. Zapewne prawdziwe jest więc twierdzenie, że „rzymski senator był zależny od głosów ludu nie tylko dlatego, że chciał sobie zapewnić siłę polityczną czy prestiż społeczny, ale w wielu przypadkach chodziło mu po prostu o zapewnienie i pomnożenie fortuny" ${ }^{51}$. Kiedy zatem weźmie się pod uwagę przeszkody, na jakie trafiał rzymski wyborca, próbując egzekwować swoje prawa wyborcze, również apolityczność kampanii wyborczej i brak wyborczego programu, można zadać istotne pytanie: dlaczego ktoś poza wąskim kołem elity rządzącej w ogóle zadawał sobie trud przychodzenia na wybory, „dlaczego część obywateli w przeciwieństwie do zdecydowanej większości niezainteresowanej wyborami, jednak się im po-

nacie, ani na zebraniach ludu, lecz tak się zachowywać, by senat na podstawie twego dotychczasowego życia uważał, że i w przyszłości będziesz obrońcą jego autorytetu, by ekwici rzymscy oraz ludzie zacni i zamożni wnosząc z przeszłości widzieli w tobie zwolennika ładu i spokoju (...)", przekł. J. Wikarjak.

${ }^{48} \mathrm{Na}$ ten temat zob. przede wszystkim K. Sandberg, The concilium plebis as a legislative Body during the Republic, [w:] U. Paanen, Senatus Populusque Romanus. Studies in Roman Republican Legislation, Helsinki 1993, s. 74-96.

${ }^{49}$ H. Mouritsen, Plebs and Politics..., s. 92, przyp. 3; badacz dodaje, że inaczej przedstawiała się sprawa w wypadku trybunów ludowych, którzy w zasadzie powinni reprezentować interesy ludu, ale zazwyczaj tego nie robili. Por. P.A. Brunt, The Fall of the Roman Republic and related essays, Oxford 2013, s. 36: „urzędnicy nie formowali rządu we współczesnym sensie".

${ }^{50}$ A. Yakobson, Elections..., s. 177, stwierdza, że każdy, kto uważa wybory w Rzymie za apolityczne, porównuje je ze współczesnymi. Badacz podaje przykłady upolitycznienia wyborów w Rzymie, ibidem, s. 148-183. Inni historycy mają jednak wiele wątpliwości co do przedstawionych przez niego tez. Zob. np. W. Nippel, Roman Voters. Rec. Alexander Yakobson: Elections and Electioneering in Rome. A Study in the Political System of the Late Republic. (Historia Einzelschriften 128.) PP 251, Stuttgart 1999, „The Classical Review” 2000, 50, s. 519.

${ }^{51}$ A. Yakobson, Elections..., s. 119. 
święcała" ${ }^{52}$. A to tym bardziej, że w Rzymie nie było żadnej ideologicznej zachęty do wzięcia w nich udziału, i nikogo nie przekonywano o obowiązku głosowania ${ }^{53}$.

Niestety, w antycznych źródłach nie znajdziemy bezpośredniej odpowiedzi na te pytania, a opinie formułowane przez współczesnych historyków są w tej materii czystymi spekulacjami. Na przykład Veyne uważa, że „wybory w Rzymie nie były całkiem poważne”. Sądzi on mianowicie, że wyborcy nie mieli wpływu na jakiekolwiek zmiany polityczne, a musieli jedynie wybierać między podobnymi kandydatami należącymi do tej samej klasy. Nie oddawano głosów po to, by ustanowić, kto będzie rządził, lecz wybierano kilkudziesięciu urzędników, którzy każdego roku obejmowali poszczególne urzędy, które miały charakter militarny, prawny itp. Innymi słowy chodziło o obsadzenie tych stanowisk, które współcześnie zwykle powierzamy fachowcom. Zdaniem Veyne’a w źródłach tak często mówi się o wyborach dlatego, że w przypadku wyboru na te urzędy dostępowano zaszczytów, od których zależała dignitas każdego z nobilów, a historia była pisana właśnie przez nich ${ }^{54}$.

Również E. Flaig uważa, że wybory były ważne dla arystokracji, dla plebsu zaś były interesujące o tyle, o ile były ważne dla arystokratów ${ }^{55}$. Zdaniem historyka wielu obywateli pokonywało długą drogę na wybory po to, by wyświadczyć grzeczność określonym kandydatom, i było to częste zachowanie się wyborców, dzięki któremu mogli oni podkreślić swoje zna-

${ }^{52}$ H. Mouritsen, Plebs and Politics..., s. 91, 96; por. M. Jehne, Who attended..., s. 227.

${ }^{53}$ M Jehne, Who attended..., s. 227, słusznie zauważa, że nawet we współczesnych demokracjach nie każdego udaje się zachęcić do pójścia na wybory. Por. H. Mouritsen, Politics..., s. 58. Historyk podkreśla jednak, że obecnie uczestnictwo w głosowaniu jest wolnym wyborem obywateli uprawnionych do głosowania, ponieważ w praktyce wszyscy mają możliwość i warunki, by oddać swój głos, natomiast nieuczestniczenie w wyborach uważane jest za niefortunne i sprzeczne z ideałami demokracji.

${ }^{54}$ Zob. P. Veyne, Brot und Spiele. Gesellschaftliche Macht und politische Herrschaft in der Antike, tłum. Z francuskiego K. Laermann i H.R. Brittnacher, Frankfurt am Main New York 1988, s. 364. Zdaniem badacza urzędy rzymskie nie są „odpowiednikami naszego ministerstwa, lecz raczej tytułami szlacheckimi”. Podobnie uważa H. Mouritsen, Plebs and Politics..., s. 94. A. Yakobson, Elections..., s. 119, nie podziela tych poglądów.

55 E. Flaig, Entscheidung..., s. 79, por. idem, Zrytualizowana..., s. 167. 
czenie, a jednocześnie „zasygnalizować swoją bliskość z niektórymi senatorami”. Jeśli ich kandydat wygrał wybory, to oni sami uzyskali „dostęp do wielu, normalnie zamkniętych dla nich zasobów. Faktycznie zatem to lud rozstrzygał, kto wygra wybory, ale efekty tych decyzji akurat dla niego, jako całości, nie miały specjalnego znaczenia" ${ }^{56}$. Podobnie uważa M. Jehne, podkreślając szczególnie fakt, że nie było jakiegoś konkretnego programu politycznego, nie obiecywano też polepszenia warunków życia, natomiast wykazywano się niezwykłą „szczodrością”57. A przyszli wyborcy, skoro nie wybierali jakiejś polityki, wybierali konkretne osoby, które musiały zrobić wszystko, by właśnie je zechciano polubićs ${ }^{58}$. Dla przeciętnego wyborcy, który nie znał kandydatów, byli oni do siebie bardzo podobni, pochodzili z tej samej klasy społecznej, mieli podobne osiąnnięcia, także kampanie wyborcze w zasadzie nie różniły się od siebie. Jedynym obszarem, w którym kandydaci mogli zwiększać swoje wydatki bez limitu, były largitiones; nie można było już bowiem pomnożyć liczby osób towarzyszących na forum ani poprawić prezencji, a na krótko przed wyborami nie można już było nawet poprawić swoich osiągnięć (na przykład militarnych) ${ }^{59}$. Kandydaci, którzy chcieli zrobić karierę, musieli zatem liczyć się z koniecznością przekupywania wyborców, a do tego doprowadziło tak wyraźne spersonalizowanie polityki oraz brak jej programowego ukierunkowania. „Mówiąc nieco uszczypliwie, oligarchowie płacili za to, że wynik wyborów (...) nie miał dla głosujących znaczenia"60.

${ }^{56}$ E. Flaig, Zrytualizowana..., s. 167.

57 M. Jehne, Who attended..., s. 228; por. H. Mouritsen, Plebs and Politics..., s. 95: „To właśnie apolityczna natura wyborów sprawiała, że dla większości mogły być one nieważne".

${ }^{58}$ E. Flaig, Entscheidung..., s. 79.

59 M. Jehne, Beeinflussung..., s. 64.

${ }^{60}$ E. Flaig, Zrytualizowana..., s. 166, por. s. 165: „Gdyby rezultat wyborów miał istotne znaczenie dla głosujących, wówczas ich rzeczywiste zaangażowanie nie miałoby charakteru sporadycznego. Rzadko się bowiem zdarzało, że lud rzymski, a więc warstwy niearystokratyczne, sam z siebie podejmował działania, aby określonym osobom zapewnić zwycięstwo. Z reguły zdarzało się to tylko po niepowodzeniach militarnych. Wyborcy, a zwłaszcza przedstawiciele wyższych klas majątkowych, starali się w takiej sytuacji przeforsować na urząd konsula doświadczonego, albo rokującego nadzieje zdolnego wodza. Tak 
Współcześni badacze są skłonni uważać przekupstwo za niezgodne z prawdziwą formą wyboru, ale łatwo zauważyć, że przekupstwo stało się tak konkurencyjne, jak inne elementy walki wyborczej ${ }^{61}$. W każdym razie akurat ten element kampanii mógł być dla wyborców - obywateli interesujący. Mógł, ale nie musiał, jak słusznie uważa M. Jehne. Zdaniem badacza bowiem dla wielu wyborców bardzo ważna była sama przynależność do jakiejś grupy wewnątrz klasy, centurii czy tribus. Gradus dignitatis było potrzebą nie tylko warstwy rządzącej, lecz także warstw niższych, i to poczucie bycia częścią większej całości mogło być wystarczającym powodem, ażeby motywować do pójścia na wybory ${ }^{62}$, albowiem uczestnictwo w zgromadzeniach tribusowych i centurialnych integrowało wyborców jako obywateli ${ }^{63}$. I chociaż niewielu brało w tym udział, to fakt ten nie stanowił jakiegoś problemu. I to należy szczególnie dobitnie podkreślić. W świecie współczesnych demokracji może wydawać się zdumiewające, że w Rzymie nikt się tym nie przejmował ${ }^{64}$. Nie czytamy bowiem nigdzie o jakimś niezadowoleniu z tego powodu czy też o jakichś propozycjach reform, które zmieniłyby taki stan rzeczy. W Rzymie nigdy nawet nie pomyślano o tym, by płacić obywatelom za udział w wyborach (jak to było w Atenach). Zdaje się, że należy spojrzeć na to zagadnienie w następujący sposób: „Ci, którzy brali udział w zgromadzeniach, byli uosobieniem populus Romanus, a zatem było zupełnie nieważne, ilu obywateli nigdy tu się nie pojawiło (...), ponieważ ci, którzy brali w nich udział, stanowili właśnie populus Romanus, i taki stan

się zdarzyło w roku 148 i 108 przed Chr., gdy wybory kolejno wygrali Scypion Emilianus i Gajusz Mariusz".

${ }^{61}$ A. Yakobson, Secret ballot and its effects in the late Roman Republic, "Hermes” 1995, 123, s. 441. O nowym spojrzeniu na kwestie ambitus zob. W. Schuller, Ambitus. Einige neue Gesichtspunkte, „Hyperboreus” 2000, 6, s. 349-361.

${ }^{62}$ M. Jehne, Integrationsrituale..., s. 98 i n. Nieco inną symbolikę miały komicja trybusowe, jak już była o tym mowa, miały one charakter egalitarny, każda tribus miała szansę głosowania jako pierwsza.

${ }^{63}$ M. Jehne, Integrationsrituale. .., s. 106. Por. K.J. Hölkeskamp, Rekonstruktionen..., s. 62: „Poziome i pionowe, hierarchiczne i egalitarne struktury przynależności uzupełniały i nakładały się na siebie, tworząc w ten sposób gęstą sieć, która zawierała każdego obywatela, każdą grupę społeczną, każdy stan i status".

${ }^{64}$ M. Jehne, Who attended..., s. 234; por. H. Mouritsen, Politics..., s. 57 i n. 
rzeczy był wygodny dla senatorów, a zaszczytny dla contionales, cała reszta zaś była kompletnie nieważna" ${ }^{65}$.

Można powiedzieć, że udział ludu w głosowaniu zawierał w sobie pewien element abstrakcji, ponieważ indywidualne głosy były łączone „W bloki” i w ten sposób efektywnie wyeliminowane zostało konwencjonalne znaczenie ilościowe frekwencji, albowiem nie było miejsca na jakąkolwiek zachętę, bodziec do zwiększenia udziału w wyborach. Masowe w nich uczestnictwo było zgoła nieistotne. I może dlatego sytuacja wyborcza, z jaką się spotykamy u schyłku republiki rzymskiej, nie powinna być uznana za jakąś degenerację instytucji ludowych zgromadzeńn ${ }^{66}$. Jak bowiem słusznie stwierdza nasz współczesny historyk, „z tym wszystkim jest rzeczą oczywistą, że suwerenność ludu, biernego i praktycznie niemego, była suwerennością arbitra, a nie efektywnie rządzącego i że właściwa gra polityczna toczyła się między czynnikiem aktywnym, to jest utrzymującym w ruchu machinę państwową magistratami (i trybunami), oraz senatem, jedynym w państwie organem deliberacyjnym i jedynym forum, na którym panowała wolność słowa" ${ }^{67}$.

\footnotetext{
${ }^{65}$ M. Jehne, Who attended..., s. 234. Por. G. Laser, op. cit., s. 58.

${ }^{66}$ H. Mouritsen, Politics..., s. 58.

${ }^{67}$ A. Ziółkowski, op. cit., s. 292 i n.
} 